\title{
A STUDY OF DEIXIS IN THE INTERVIEW BETWEEN BARACK OBAMA AND CHUCK TODD IN MEET THE PRESS
}

\author{
Widya Lestari', Ahmad Ardillah Rahman ${ }^{2}$ \\ State Islamic University of Sunan Ampel Surabaya, Indonesia ${ }^{\mathbf{1}}$, \\ Monash University, Australia ${ }^{2}$ \\ widyalestari34@gmail.com¹, aarah4@monash.edu²
}

\begin{abstract}
The research investigates the types of deixis, the types of reference and the reference meaning used by Barack Obama and Chuck Todd in "Meet the Press" interview. In analyzing the data, the researcher uses descriptive qualitative method. The results of the research show that from the total of 372 deixis from 84 conversation, all the five types of Levinson's (1983) deixis can be found. Regarding the references, President Barack Obama contains both anaphora and cataphora.
\end{abstract}

Keywords: deixis; reference; Barack Obama; "Meet the Press" interview.

\section{INTRODUCTION}

In doing communication, everyone has a different way to make other people easy to understand his/her messages. To avoid misinterpretation or misunderstanding of what the speaker says, it is important to know the context of the speaker's utterances, so it will help us to understand the utterances more easily. In every communication in our daily life, deixis is always present, and the purpose of using deixis in a sentence is to point at something such he, here, now, etc.

According to Levinson (1983:54), deixis is the single obvious way in which the relationship between language and context is reflected in the structures of language themselves. Levinson also categorizes the deixis into five kinds, they are person deixis, spatial deixis, temporal deixis, discourse deixis and social deixis. Deixis appears in spoken language and written language. In this research,the researcher wants to explain about the usage of deixis in spoken language. In spoken language, people can recognize a person, a place and time of deixis because the one who is being talked about by the speaker is known by the hearer and the time when the speaker utters some utterances is also clear.

To avoid misinterpretation, in studying deixis we also have to talk about references. According to Yule (1996:17), reference is an act in which a speaker, or writer uses linguistic form to enable a listener, or a reader to identify something. Reference is clearly tied to the speaker's goals and beliefs in the use of language. Reference is divided into two types, they are, endophoric reference and exophoric reference. Endophoric reference is divided further 
into two types, they are, anaphora and cataphora. Anaphora is looking back in the text for their interpretation. Cataphora is looking forward in the text for their interpretation.

Interview is one of the examples of a formal conversation between two or more people to get some information. "Meet the Press" is a weekly American television news/interview program that is broadcasted on NBC. This research focuses on deixis in the interview between Barack Obama and Chuck Todd in the "Meet the Press" event. This study deals with every utterance that is related to the deixis and reference. There are two items that are elaborated in this research. First, the analysis focuses on the kinds of deixis used by Barrack Obama and Chuck Todd in the "Meet the Press" event. Second, the researcher focuses on the kinds of reference and referent that appear in the "Meet the Press" interview.

\section{REVIEW OF LITERATURE}

\subsection{Deixis}

Levinson (1983:54) explains that deixis concerns with the ways in which languages encode or grammaticalize features of the context of utterance or speech events. And this also concerns with ways in which the interpretation of utterance depends on the analysis of that context of utterance. He also adds that deixis has a relevance with the study of pragmatics (see also Mey, 2001).

Yule (1995:9) also states that deixis is actually the way in which a relationship between language and the context is built. Deixis is a technical term (from Greek) for one of the most basic things we do with utterances. It means 'pointing' via language. Any linguistic form used to accomplish this 'pointing' is called 'deictic expression'. Deictic expressions are also sometimes called indexical. They are among the first form to be spoken by very young children and can be used to indicate people via person deixis (I, you), time or temporal deixis (now, yesterday), location or spatial deixis (here, there), discourse deixis and social deixis.

\subsubsection{Types of Deixis}

There are five types of deixis. They are: person deixis, Spatial deixis (place), temporal deixis (time), discourse deixis, and social deixis.

\section{Person Deixis}

Levinson (1983:62) states that person deixis concerns the encoding of the role of participants in the speech of event in which the utterance in question is delivered. In other words, person deixis is described as expressions which refers to a person who the speaker intends to refer. 


\section{Spatial Deixis}

Place or space deixis concerns the specification of locations relative to the participants in the speech events. There are some pure place deictic words in English the adverbs here and there, and the demonstrative pronouns this and that. For example: I'm waiting to say I'm having a marvelous time here.Briefly, place deixis is an expression used to show the location of the participant in the speech event.

\section{Temporal Deixis}

Levinson (1983:62) states that time deixis concerns the encoding of temporal point and spans relative to the time at which an utterance was spoken (or a written message inscribed). Temporal deixis is commonly grammaticalized in the adverb of time, such as now and then, yesterday, etc.

According to Yule (1996:14), English has only two basic forms, the present and the past. The present tense is the proximal form and the past is distal form. For example:

Present : I live here now.

Past : I lived there than.

Hence, from the explanation above it is clear that time deixis is an expression of certain period of time when the utterance is produced by the speaker.

\section{Discourse Deixis}

Discourse or text deixis relates to the use of expression within some utterances that refer to some portions of discourse that contains the utterance (Levinson, 1983:85). The deictic words used here are the demonstrative this and that. For example:

- "I bet you haven't heard this story." ('This' refers to an upcoming portion of the discourse).

- " "That was the funniest story I've ever heard." ('That' refers to a prior portion of the discourse).

Discourse deixis deals with "the encoding of reference to portions of the unfolding discourse in which the utterance (which include the text referring expression) is located (Levinson, 1983:62). In other words, discourse deixis is an expression used to refer to certain discourse that contains an utterance and has the relation with the surrounding text.

\section{Social Deixis}

Social deixis refers to the level of the relationship between a person and information. Levinson (1983:89) states that it concerns with the aspects of sentence which reflect or are established by certain realities of the social situation in which the speech act occurs. There are 
two basic kinds of socially deictic information to be encoded in different languages around the world, they are relational and absolute.

\subsection{Reference}

According to Yule (1996:17) reference is an act in which a speaker, or writer uses a linguistic form to enable a listener, or reader to identify something. Halliday and Hasan (1976:31) also argue that reference is the identity of the particular thing or class of things that is being referred to. Halliday and Hasan (1976) classifies references into two types, they are, exophoric reference and endophoric reference. Exophoric reference is situational, while endophoric is textual (1976:33). Exophoric reference is looking outside the text to the situation in which the text occurs for the identity of the item being referred to. While endophoric is the use of a word or phrase to refer to something either preceding it or following it within a text or discourse.

Endophoric reference also establishes itself in two different ways: anaphora and cataphora. Anaphora is a process of continuing to identify exactly the same entity as denoted by the antecedent (Yule, 1996:23). Or it can be said that the use of word to introduce someone or something already mention. Cataphor is the use of a word (typically a pronoun) to introduce someone or something that is more fully identified later (Yule, 1996:127; Sugiharto, 2004).

\section{RESEARCH METHODS}

In conducting this study, the researcher used descriptive qualitative to describe the five types of deixis, they were person deixis, spatial or location deixis, time or temporal deixis, discourse deixis and social deixis and also the types of reference, they were anaphora and cataphora. The data source of this research was the an interview transcription between Barrack Obama and NBC's chuck Todd in "Meet the Press" on September $7^{\text {th }}$, 2014. and the data was the utterance of Barack Obama and Chuck todd in "meet the press" interview.

\section{FINDINGS AND DISCUSSIONS}

This part presents the results of the research related to deixis and references and discusses the main points of the research.

\section{1 Types of Deixis}

After finding all the data from the interview of Chuck Todd to President Barack Obama in "Meet the Press", the researcher found 372 words of deixis. There are five deixis found in this study, they are, person deixis, spatial deixis, temporal deixis, discourse/text deixis, and 
social deixis.

\subsubsection{Person Deixis}

Person deixis is described as expressions in which refers to person who the speaker intend to refer. It includes "I","we", "you", etc. The data below is the example of person deixis.

PRESIDENT OBAMA: I'm preparing the country to make sure that we deal with a threat from ISIL. Keep in mind that this is something that we know how to do. We've been dealing with terrorist threats for quite some time. (P.1, No.4).

The sentence above is from President Obama as the speaker, he tried to answer the question that Mr. Chuck todd gave him. This sentence explains about the preparation that Mr. President obama did for his country to face the threat from ISIL.

From the sentence above, there is a word deixis that used by Obama. It seems in the first sentence. The word " $I$ ", it refers to someone and speaker. According to Levinson the word " $I$ "was categorized as a singular pronoun of the first person deixis. The word "I" refers to the role of person deixis in which the utterance narrated by one person. So, it is to the speaker of the interview named President Barack Obama. He was the one of the guest star in the interview event.

The second, there was a word "We" that can be categorized as plural pronoun of the first person deixis. it can be indicated as a group of speaker because the word "We" is to point themself. "We" refers to the country of the United States. It can represent President Barack Obama and his society in the United States.

\subsubsection{Spatial Deixis}

Spatial Deixis concerns the specification of locations relative to the participants in the speech events. There are some words that included in deictic words such as the adverbs here and there, and the demonstrative pronouns this and that.

PRESIDENT OBAMA: As usual. And we're going to have to get U.S. military assets just to set up, for example isola-- isolation units and-- and equipment there, to provide security for public health workers surging from around the world. If we do that, then it's still going to be months before this problem is controllable in Africa. (P. 9, No. 48)

From the sentence above, President Obama as the speaker, he explained the efforts of U.S to build some health infrastructure in Africa, such isolation units and some equipment that African people needs to face their problem, because over there, they had faced an Ebola disease and they do not have enough public health. 
In this sentence, there is a word "there". Based on Levinson's theory it can be categorized as spatial deixis where it encodes the spatial locations relative to the location of the participants in the speech event. The word "there" also can be called as adverb of place used for far distance. In the sentence above, the deictic word "there" explained the condition of African people who faced the Ebola disease.

\subsubsection{Temporal Deixis}

As Levinson said that temporal deixis concerns the encoding of temporal point and spans relative to the time at which an utterance was spoken (or a written message inscribed). It usually appears as adverb of time, such as now and then, yesterday, etc. The data below is the example of temporal deixis.

PRESIDENT OBAMA: We just yesterday announced the fact that we had taken out the top leader of Al-Shabaab the terrorist-- organization in Somalia.(P.1, No.4)

That sentence is the utterances of President Obama when announcing that his country has already prepared for the threat from a terrorist, especially, ISIL group. Obama also explained that he had already caught the leader of al-Shabaab terrorist in Somalia the day before.

From the sentence above, it seems the deixis "yesterday", indicates adverb of time. "Yesterday" is used by the speaker to show the situation that happens in the past time. Levinson identifies, "yesterday" as temporal or time deixis, which is encoding time of lated to the utterance.

\subsubsection{Discourse or Text deixis}

Discourse concerning to the use of expression within some utterances refers to some portion of the discourse that contains the utterance (Levinson, 1983:85). It usually uses demonstrative word such as here, this and that. The data below is the example of discourse deixis.

PRESIDENT OBAMA: This speech will allow Congress, I think, to understand very clearly and very specifically what it is that we are doing but also what we're not doing. We are not looking at sending in 100,000 American troops. (P.3, No.10).

The speaker of this event is President Obama. He explains that as a president he needs to protect his society from any threat, and he thinks that he needs to deliver his speech to make the congress know and understand it very clearly about the government plans that they will do and they don't do. The word "this" in the first part of Obama's utterances can be categorized as discourse deixis which is to talk about people or things near us. In this sentence the word "this" is followed by a noun to show proximity. 


\subsubsection{Social Deixis}

The level of the relationship between a person and information can be called as a social deixis. It is relevant with Levinson's statement that it concerns with the aspect of sentences which reflect or establish certain realities of social situation in which the speech act occurs. It usually uses the word, relational and absolute such as the data below.

CHUCK TODD: Well, I think I need to pre-book you for next week, because I got another 35 questions. So with that, I'm going to leave it there, Mr. President. But thank you very much.(P.15, No. 83)

The sentence above is the last conversation between Chuck Todd and President Obama. In the sentence above, Chuck Todd as a speaker has a plan to invite President Obama again in the Meet the Press event. In the last sentence, Chuck Todd calls Obama with "Mr. President".

Based on Oxford Dictionary, the word "President" means the leader of a republic country, especially, the United States. According to Levinson, there are two types of social deixis, they are, relational and absolute. Relational social deixis is where the form of the word is used to indicate the relative social status of the addressee. By contrast, absolute deixis is a deictic reference that is usually expressed in certain forms of address which will include no comparison of the ranking of the speaker and addressee. So, by the sentence above the word 'Mr. President' can be categorized as absolute social deixis.

\subsection{Types of References and Their Referent}

Regarding references, both anaphora and cataphora can be found in this research.

\subsubsection{Anaphora}

Anaphora is the use of word to introduce someone or something already mentioned. The Data below is the example of anaphora.

CHUCK TODD: Mr. President, welcome back to your 12th appearance on Meet the Press. (P.1, No.1)

The sentence above is the opening of an interview. Chuck Todd as a speaker or host starts to greet his guest star, Mr. Obama, by welcoming his appearance in Meet the Press. That sentence contains anaphoric reference. Anaphora is used to introduce someone or something that is already mentioned before. In the sentence above, the word "Your" refers to the addressee, that is, President Obama.

\subsubsection{Cataphora}

Cataphor is the use of a word (typically a pronoun) to introduce someone or something that is more fully identified later (Yule,1996:127). It can be found in data as follows. 
PRESIDENT OBAMA: Well, Americans shouldn't be concerned about the prospects of contagion here in the United States, short term. Because this is not an airborne disease.(P.8, No. 40)

In the conversation above, President Obama as the speaker explains about what American people concerned can do to the Ebola disease that African people are suffering at that time. But President Obama also informs that Ebola is an airborne disease so they do not need to worry about that. The word "here" in the sentence above is an adverb of place which is used to demonstrate a place that is relatively close to the speaker. The word "here" in the sentence is a cataphoric reference, which is used to identify someone or something that is mentioned later, that is, the words 'the United States'. It can be seen in President Obama's statement that he stressed the word "here" and followed by 'the United States' to give information that the location of the speaker in the speech event is in the United States. So from the explanation, it is clear that the adverb of place "here" refers to the United States based on the context of the utterances.

\section{CONCLUSION}

The results of the study that have been obtained show that there are five types of deixis that are employed by Barack Obama and Chuck Todd in the "Meet the Press" interview. They are, person deixis, spatial deixis, temporal deixis, discourse/text deixis, and social deixis. In this case, the most often apparent types of deixis found in this interview are the use of the words $I$ and We derived from Barack Obama's utterances. The word $I$ in this interview refers to President Obama himself, while the pronoun We are refers to President Obama and his Government. Whereas, for Chuck Todd as a host in this speech event, the most often apparent types of deixis that he uses are the second person pronoun ' $Y o u$ ' which refers to President Obama as the addressee in this speech event and the first Pronoun $I$ which refers to himself (Chuck Todd). Then, the types of reference that are mostly applied in this interview is anaphoric reference.

\section{REFERENCES}

Halliday, M.A.K and Hasan, R. (1976). Cohesion in English. London: Longman.

Levinson, S.C. (1983). Pragmatics. Cambridge: Cambridge University

Mey, J.L. (2001). Second Edition: Pragmatics An Introduction. Malden, Massachusetts: Oxford University Press

Sugiharto, S. (2004). Reference, Anaphora, and Deixis: An Overview. Vol. 4 No. 2.Atma Jaya Catholic University.

Yule, G. (1996). Pragmatics. New York: Oxford University Press. 